\title{
SINTESA TASAWUF AKHLAKI DAN FALSAFI DALAM TEKS AL-MANHAL ${ }^{1}$
}

\author{
A Synthesis of Akhlaki Sufism and Falsafi \\ in The Text of al - Manhal
}

\author{
Syofyan Hadi \\ Jurusan Bahasa dan Sastra Arab Fakultas Adab IAIN Imam Bonjol Padang \\ Kampus Lubuk Lintah-Kuranji-Padang-Sumatera Barat \\ Email: syofyanhadi@gmail.com
}

Naskah diterima tanggal 04 September 2015. Naskah direvisi tanggal 26 September 2015. Naskah disetujui tanggal 02 November 2015.

\begin{abstract}
Abstrak
Hal yang sudah menjadi kesepakatan para peneliti bahwa corak tasawuf yang berkembang di Nusantara dibagi kepada dua kelompok besar; yaitu tasawuf dengan model akhlaki dan tasawuf dengan corak falsafi. Adapun tasawuf dengan corak akhlaki adalah aliran tasawuf yang lebih berorientasi kepada intensitas amaliyah dan lebih bertujuan dalam rangka pembentukan akhlak mulia bagi pengikutnya. Sementara tasawuf dengan corak falsafi adalah aliran tasawuf yang lebih identik dengan pemikiran-pemikiran filosofisnya terutama konsep-konsep tentang Tuhan, makhluk, pencipataan semesta dan sebagainya. Kedua aliran tasawuf ini seakan tidak pernah menemukan titik temu dan kesamaan bahkan sejarah berdarah pernah ditorehkan akibat rivalitas keduanya. Apa yang terjadi dan dialami Hamzah Fanshuri dan pengikutnya di Aceh ataupun Syaikh Siti Jenar di Jawa adalah fakta sejarah yang membuktikan betapa kuatnya rivalitas kedua ajaran ini. Akan tetapi, naskah al-Manhal karya Syaikh Isma'il al-Minangkabawi ternyata memberikan fakta berbeda di mana ajaran tasawuf akhlaki dan falsafi bisa bersatu di Nusantara. Melalui kitab al-Manhal ini Syaikh Ismail al-Minangkabawi mencoba melakukan sintesa antara konsep akhlaki dan falsafi dalam bungkus ajaran tarekat Naqsyabandiyah Khalidiyah.
\end{abstract}

Kata kunci: akhlaki, falsafi, al-Manhal, sintesa.

\begin{abstract}
It has been the agreement among the researchers that Sufism developed in Indonesia was divided into two major groups; namely akhlaki Sufism and falsafi Sufism. In akhlaki Sufism, the teachings focused on the intensity of amaliyah (religious activities) and the formation of beautiful character for the followers. While falsafi Sufism focused on philosophical thoughts, especially the concepts of God, creatures, the creation of the universe and so on. These both Sufism teachings have never found agreement and similarity, even bloody history occured due to the rivalry. What happened and experienced by Fanshuri Hamzah and his followers in Aceh or Shaikh Siti Jenar in Java are the historical facts that prove how strong the rivalry of both teachings. However, the manuscript of al-Manhal by Shaykh Isma'il al-Minangkabawi shows different facts where both teachings can be united in Indonesia. Through this book 'al-Manhal', Shaykh Ismail Minangkabawi attempted to make a synthesis between akhlaki and falsafi in the frame of Naqshbandi Khalidiyah teachings.
\end{abstract}

Keywords: akhlaki, falsafi, al-Manhal, synthesis

1 Artikel ini adalah bagian dari pembahasan disertasi penulis di Sekolah Pascasarjana (SPs) Universitas Islam Negeri (UIN) Syarif Hidayatullah Jakarta dengan judul "Sastra Sufistik Nusantara: Orisinalitas Gagasan dan Stilistika Karya Syaikh Isma’il al-Minangkabawi” (2014). 


\section{PENDAHULUAN}

B anyak kajian yang telah dilakukan peneliti yang menyimpulkan bahwa masuk dan berkembangnya Islam di Nusantara dimotori oleh gerakan sufisme. Para sufi dianggap sebagai kelompok yang paling berperan dalam penyebaran Islam di Nusantara dengan kharismatik dan keilmuan yang mereka miliki. Pada saat bersamaan sejarah juga mencatat bahwa di Nusantara berkembang dua corak aliran sufistik yang memiliki pengaruh besar dalam penyebaran ajaran Islam di Nusantara. Pertama, tasawuf dengan corak 'amalī yang lebih dikenal dengan sebutan tasawuf akhlāqì dengan karakter yang lebih berorientasi pada intensitas amal dan ibadah praktis dalam rangka pembentukan akhlak. Tasawuf akhlāqī ini biasanya dihubungkan dengan model pengamalan Abū hāmid al-Ghazali (w. 505 H/1111 M) yang berwawasan moral-praktis dan bersandarkan kepada Alquran dan al-Sunnah (Huda, Shoki, 2008: 4). Kedua, tasawuf dengan kecenderungan pemikiran filsafat atau yang lebih dikenal dengan sebutan tasawuf falsafī (Sholihin, Muhammad, 2005: 15). Tasawuf falsafī merujuk pada konsep tasawuf yang dihubungkan ajaran wahdat al-wujū $d$ yang digagas Ibn 'Arabī dan disebut sebagai konsep sufistik yang dipengaruhi oleh aliran mistik di luar Islam, terutama Yunani yang dikenal dengan istilah mistisisme panteistik (Noer, Kautsar Azhari, 1995: 210). Konsep ajarannya dimulai dari ajaran al-hulūl yang dipopulerkan al-hallāj, alittihād yang dikemukan al-Bushāmī, wahdat alwujūd yang dirumuskan Ibn 'Arabī hingga al-insān al-kāmil yang dikembangkan al-Jìlī (Sholikhin, Muhammad, 2010: 29-32).

Dalam konteks Nusantara, tasawuf akhlāqì yang merujuk pada model al-Ghazalī ini dikembangkan di Sumatera oleh al-Ranirī beserta murid-muridnya kemudian dilanjutkan oleh Abd al-hamad al-Palimbanì dan lainnya (Feener, R. Michael, Sevea, Terenjit, 2009: xxiii). Di Jawa, ajaran tasawuf ini dikembangkan oleh Wali Sanga dan murid-muridnya. Sementara tasawuf falsafi dikembangkan oleh beberapa tokoh sufi ternama seperti Hamzah al-Fanhūrī, Shams al-Dīn alSumatrānī (Johns, A.H, 2011: 229-231). Abd alRaūf al-Sinkilī (Fathurahman, Oman, 1999: 5262), di kawasan Sumatera dan Syaikh Siti Jenar di tanah Jawa (Solihin, M, 2005: 6). Kedua corak ajaran sufstik ini kemudian dikembangkan lewat tarekat yang diajarkan seperti di surau di Sumatera Barat, pesantren di Jawa dan sebagainya (Shihab, Alwi, 2001: 32 dan Azra, Azyumardi, 2003: 81).

Menariknya adalah bahwa ternyata membagi ajaran tasawuf yang berkembang di Nusantara tidaklah perkara mudah dan harus selalu hitam putih. Terdapat kompleksitas perkembangan ajaran tasawuf di Nusantara seperti kompleksnya karakter dan corak keberagamaan masyarakat Nusantara itu sendiri. Membagi model tasawuf yang berkembang di Nusantara ke dalam dua corak besar seolah menafikan fakta lain, di mana terdapat poros lain dari ajaran tasawuf yang lebih adaptif dan akomudatif terhadap keduanya. Sehingga, kedua corak ajaran tasawuf ini tidaklah kemudian harus selalu dipertentangkan antara satu dengan lainnya dan seakan tidak pernah ada titik temu antara keduanya.

Dalam konteks inilah penulis ingin melihat corak ajaran sufistik Syaikh Isma'il al-Minangkabawi yang dianggap sebagai salah satu tokoh pembaru tasawuf di Nusantara. Melalui analisis terhadap salah satu karyanya berjudul al-Manhal al-Adhb li-dhikr al-qalb (selanjutnya disingkat al-Manhal) akan terlihat betapa tokoh-tokoh sufi Nusantara semenjak masa lalu sebenarnya telah berusaha "mendamaikan" dan menyatukan konsep-konsep ajaran dasar dari corak taswuf besar yang berbeda ini dalam formulasi baru yang lebih adaptif dan akomudatif.

\section{PEMBAHASAN}

\section{Syaikh Isma'il al-Minangkabawi dan Teks al- Manhal}

Syaikh Isma'il ibn 'Abdullah al-Khalidi alSimaburi al-Minangkabawi al-Barusi al-Jawi adalah salah satu ulama asal Minangkabau yang dianggap sebagai pembawa dan penyebar pertama ajaran tarekat Naqsyabandiyah ke Nusantara. Syaikh Isma'il al-Minangkabawi menghabiskan umurnya selama 35 tahun untuk tinggal dan belajar di tanah suci kepada ulama-ulama terkemuka di sana (Solihin, 2005: 77). Tercatat Syaikh Ismail al-Minangkabawi pernah belajar kepada Syaikh Muhammad Salih Ra'is al-Syafi'i (w.1240 H), Syaikh 'Uthman alDimyati (w.1265 H), Syaikh Ahmad al-Dimyati 
(w.1270 H) ('Abd al-Jabbār, Umar, 1982: 71). Selain itu, dia juga belajar kepada Syaikh Muhammad Sa id ibn 'Ali al-Shafi'i al-Makki al-Qudsi (w. $1260 \mathrm{H}$ ) (Al-Bakrī, 2009: 924-925). Dalam bidang tasawuf tercatat bahwa Syaikh Isma'il al-Minangkabawi pernah belajar kepada Syaikh Atha'illah ibn Ahmad al-Azhari, Syaikh 'Abdullah al-Sharqawi, Syaikh Muhammad ibn 'Ali al-Shanawi, Syaikh 'Abdullah Afandi al-Arzinjani dan Syaikh Khalid al-'Uthmani al-Kurdi (w. 1242 H). Kematangan spiritualnya terjadi ketika Syaikh Isma'il al-Minangkabawi diangkat menjadi khalifah Syaikh 'Abdullah Afandi al-Khalidi (Bruinessen, Martin van, 2007: 226-227).

Setelah sekian lama menjalankan studi hingga kontempelasi rohani di Jabal Qubays Makkah serta menempa dirinya dengan pengalaman pengembaraan ke beberapa negeri Islam, Syaikh Isma'il al-Minangkabawi memutuskan untuk kembali ke tanah air. Syaikh Isma' il al-Minangkabawi tercatat pernah menentap di Singapura, kerajaan Riau Lingga, Pulau Penang, Negeri Kedah, Malaka dan Negeri Sembilan (Abdullah, Wan Mohd. Shaghir, 1993: 118-119.). Setelah sekian lama tinggal di Nusantara, Syaikh Isma'il al-Minangkabawi kembali ke Makkah dan meninggal dunia di Jabal Qubays Makkah pada tahun 1275 H/1840 M.

Di antara karyanya yang belum banyak diketahui publik dan sekaligus merupakan karya yang paling fenomenal dari semua karyanya adalah teks al-Manhal. Karya ini disebut fenomenal karena karya inilah yang menunjukan jati diri Syaikh Isma'il al-Minangkabawi yang sebenarnya dalam kapasitasnya sebagai tokoh dan pengembang jaran tarekat Naqsyabandiyah di Nusantara. Teks alManhal ini pulalah yang memberikan gambaran utuh tentang konsep ajaran tasawufnya di Nusantara, di samping karya ini dituangkan dalam gubahan baik-bait puisi yang indah dengan gaya susunan bahasa Arab yang sangat menawan.

Teks al-Manhal ini selesai ditulis di Riau pada hari Selasa tahun 1245 H/1811 M. Naskahnya sendiri ditemukan dan disimpan pada sebuah surau tua di Rao Pasaman Sumatera Barat. Teks al-Manhal berisi ajaran tarekat Naqsyabandiyah Khalidiyah di samping juga berisi memuat polemik pengarang dengan para penentang ajarannya di Nusantara.

\section{Kompromi Konsep al-Fayd dalam Konteks Tawassul.}

Tarekat Naqshabandiyah sebagai salah satu gerakan keagamaan yang merupakan gerakan sufi yang sudah terlembagakan dalam sebuah organisasi, tentu saja eksistensi pemimpin spiritual atau yang dalam dunia tarekat lazim disebut guru murshid menjadi sangat vital. Guru murshid adalah simbol tertinggi dalam pembimbingan spiritual yang bertugas menjadi mediator/al-wasilah (الوسيلة) untuk mengantarkan seorang murid berhubungan dan mencapai Tuhan. Dalam konteks berhubungan dengan Tuhan ini, subtansi makhluk dan hakikat Tuhan menjadi penting untuk dijelaskan. Penjelasan ini tentu saja sangat terkait dengan penjelasan tentang bagaimana posisi guru murshid tersebut sebagai mediator bagi seorang murid dalam berhubungan dengan Tuhan. Konsep itulah yang ingin dijelaskan oleh Syaikh Isma'il al-Minangkabawi dengan meminjam teori emanasinya/al-fayd (الْفَيْضِ) yang pernah dicetuskan pertama kali oleh seorang filusuf Islam bernama al-Kindī, seperti dalam bait berikut.

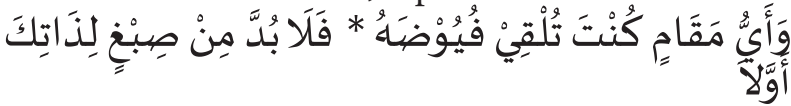

Dan mana maqām yang ada engkau menjatuhkan akan segala faydnya * itu maka tidak dapat tiada daripada bahwa engkau celup bagi zatmu itu mula-mula

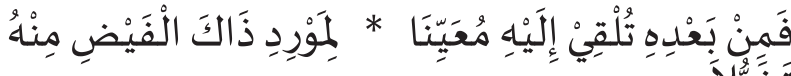

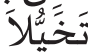

Maka kemudian daripadanya itu engkau jatuhkanlah kepadanya padahalnya menentukan * bagi Allah masuk fayd itu daripadanya ditakhayyulkan

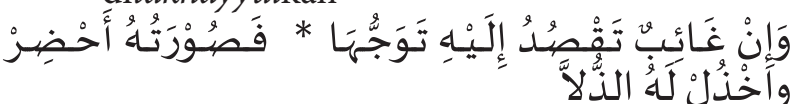

Dan jika ghaib ia niscaya engkau senghaja padanya dan kepada tawajjuh ${ }^{*}$ maka rupanya hadirkan olehmu dan hidupkan olehmu baginya itu akan cita-cita

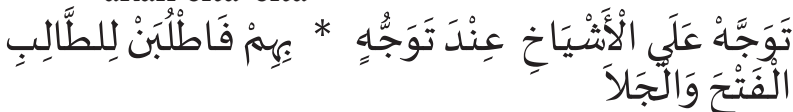

Tawajjuh olehmu kepada sekalian syaikh-syaikh tatkala tawajjuh ini ${ }^{*}$ dangan mereka itu maka tuntut olehmu bagi murid ini akan futūh dan tarang.

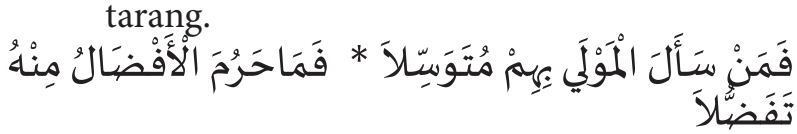


Maka siapa-siapa yang memohon ia akan Tuhan padahalnya mengambil tawassul dangan mereka itu ${ }^{*}$ maka tiadalah putus ia akan karunia daripada-Nya akan sempurna karunia

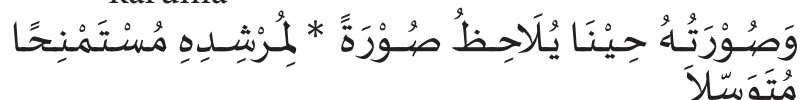

Dan rupanya itu pada satu kutika mengingatkan ia akan rupa* bagi murshidnya padahalnya menuntut dia pemberian lagi menuntut tawassul (Naskah al-Manhal, 1).

Dalam bait di atas, Syaikh Ismail alMinangkabawi menyebutkan istilah al-fayd(أَفَفْض) "limpahan" atau yang dalam istilah tasawuf falsafi dikenal dengan istilah emanasi. Teori emanasi (alfayd) dalam konteks filsafat Islam, sebagaimana dikemukakan banyak ahli adalah diperkenalkan oleh beberapa filosuf muslim ternama. Mereka adalah Abū Yūsuf Yáqūb ibn Ishāq al-Kindī (w. rา. H/^vr M), Abū Bakar Muhammad ibn Zakariya ibn Yahyā al-Razī (w. rı H/qro M), Abū Nasr Muhammad Ibn Muhammad al-Farābī (w. rщq H/я०. M) dan Abū Alī husayn ibn 'Abdullah ibn Sinā (w.

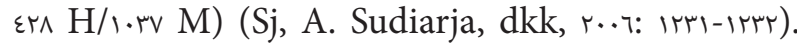
Teori emanasi (al-fayd) ini menurut konsep alFarabī dan juga filosof Islam lainnya pada intinya bertujuan untuk menjaga prinsip transendsi mutlak Tuhan (al-Khāliq) terhadap semua ciptaan-Nya (almakhlūq) (Hamdi, Ahmad Zainul, r...: rা-rr dan Masruri, M. Hadi, r..०: १।). Dalam paham al-Farābī begitu juga Ibn Sinā, bahwa proses emanasi Tuhan dimulai ketika Tuhan berfikir (al-táaqqul) tentang diri-Nya sendiri. Maka al-ta'aqqul Tuhan tentang diri-Nya ini melahirkan pancaran pertama atau yang disebut dengan akal pertama. Akal pertama ini kemudian berfikir (al-ta'aqqul) pula tentang dirinya dan melahirkan akal kedua. Akal kedua pun berfikir (al-ta'aqqul) tentang dirinya, maka muncul bintangbintang begitulah seterusnya yang melahirkan penciptaan alam semesta berikut segala makhluk dalam alam raya ini (Effendy, Mochtar, 2001: 87 dan Nasution, Harun, 1973: 27-31).

Dalam perkembangan selanjutnya akal pertama yang dianggap sebagai cikal-bakal alam semesta ini dalam dunia tasawuf kemudian disebut dengan istilah Nūr Muhammad (نور محمد) atau alhaqiqat al-muhammadiyah (الحقيقة المحمدية). Konsep Nūr Muhammad atau al-'aql al-awwal (العقل الأول) ini, menurut Ibn 'Arabì dianggap sebagai cikal bakal penciptaan semesta. Dan Nūr Muhammad ini dianggap juga sebagai realitas universal yang menghimpun seluruh realitas. Ia memiliki sifat-sifat Tuhan dan juga makhluk tergantung dari perspektif mana Dia dilihat (Mujieb, M. Abdul, dkk, 2009: 507). Oleh karena itu, dalam sosok nabi Muhammad saw yang harus lebih diperhatikan bukanlah person historisnya, akan tetapi esensinya dalam bentuk subtansi Nūr Muhammad; cahaya pilihan dalam bentuk manusia terpuji (sempurna) sebagai tajalli Tuhan yang paripurna. Melalui Nūr Muhammad itulah, person historis nabi Muhammad dikenal secara mushāhadah dan mata telanjang sebagai manusia utama yang mengatasi seluruh makhluk. Melalui keutamaannya yang mengungguli seluruh makhluk inilah, maka seluruh makhluk kemudian mengenali dan memberikan pengakuan terhadapNya. Konsepsi inilah yang kemudian dikembangkan oleh Syaikh 'Abd al-Karīm ibn Ibrāhīm al-Jīlì (w. 805 H/1405 M) yang selanjutnya melahirkan istilah alinsān al-kāmil (الانسان الكامل) “manusia sempurna” yang prototipenya adalah personaliti nabi Muhammad saw (Sholikhin, Muhammad, 2009: 105).

Seperti kebanyakan sufi lainnya, Ibn 'Arabì percaya bahwa para wali merupakan pewaris sipiritual Nabi Muhammad saw yang memperoleh cahaya Muhammad (Nūr Muhammad) tersebut (Solohin, M., Anwar, Rosihan, 2002: 72). Para sufi yang meniti jalan menuju Tuhan dengan segala kesungguhan latihan spiritualnya (al-riyādah) dan kemudian berhasil meraih cahaya márifah, akan berubah menjadi perwujudan manusia sempurna (al-insān al-kāmil). Dan Allah swt kemudian memberikan kelebihan kepada mereka yang telah sampai pada tingkat ini, berupa kemampuan untuk bermushāhadah dengan Allah swt melaui tersingkapnya tabir yang sebelumnya menjadi hijab yang menghalangi makhluk dengan Tuhan. Mereka inilah yang kemudian disebut para wali Allah swt yang bisa menjadi penolong, sekaligus penunjuk jalan bagi orang lain untuk mereka bisa pula mencapai Allah swt. Dalam konteks ajaran tarekat Naqshabandiyah, bahwa mereka yang telah mencapai kedudukan demikian disebut dengan guru murshìd al-kāmil al-mukammil مرشد الكامل) الككمل (Ibn 'Arabī, Muhy al-Dīn, 1985: 311-312).

Dari sinilah muncul gagasan sufistik Shaykh 
Isma'il al-Minangkabawi tentang perlunya menggunakan perantara dalam ibadah untuk menghubungkan murid dan Tuhan. Proses penggunaan perantara itulah yang disebutkan dengan istilah al-tawassul (التوسل), seperti dalam ungkapannya fa-man sa'ala al-mawlā bi-him

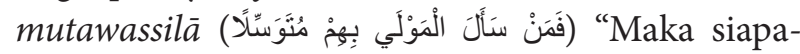
siapa yang memohon ia akan Tuhan, padahalnya mengambil tawassul dangan mereka itu". Walaupun pada praktiknya keyakinan dan praktek al-tawassul seperti demikian, juga telah dimiliki oleh sebagian pengikut tarekat lainnya dan tentu tidak terkecuali di kalangan pengikut tarekat Naqshabandiyah sendiri (Atjeh, Aboebakar, 1985: 79). Namun demikian, Syaikh Isma' il al-Minangkabawi mencoba menjelaskan gagasan al-tawassul tersebut dengan berangkat dari teori emanasi (al-fayd) yang telah berkembang di kalangan pengikut tasawuf falsafi sebelumnya. Konsep ini kemudian dikembangkan hingga memunculkan konsep Nūr Muhammad dan terwujud dalam ide al-insān al-kāmil. Di mana, bahwa hakikat Nūr Muhammad dan prototipe al-insān al-kāmil itu terwujud dalam diri para wali atau murshid yang kāmil lagi Mukammil tersebut. Dalam keyakinan para pengikut tarekat Naqshabandiyah yang diajarkan oleh Syaikh Isma'il al-Minangkabawi, bahwa murshid yang memiliki kualifikasi tertentu akan dapat menjadi mediator (alwasīlah) dan akan mengantarkan murid-muridnya untuk berhubungan atau mencapai kedekatan yang sempurna dengan Allah swt (Bruinessen, Martin van, 1992: 13). Sebab, para murshid yang kāmil lagi mukammil adalah orang yang diyakini sebagai perwujudan al-insān al-kāmil yang mampu melimpahkan kemuliannya kepada muridnya untuk bisa mencapai hakikat Tuhan. Hal itu seperti terlihat dalam beberapa bait berikut.

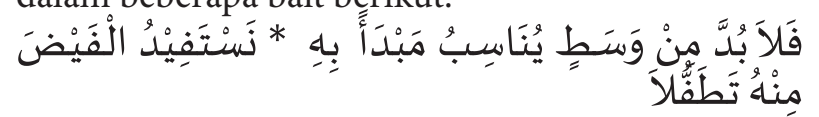

Maka tidak dapat tiada daripada wāsihah yang munāsibah ia akan jadi permulaan dangan dia jua * kita ambil akan fayd daripadanya dangan tahafful jua artinya tatumpang jua (Naskah al-Manhal, 20).

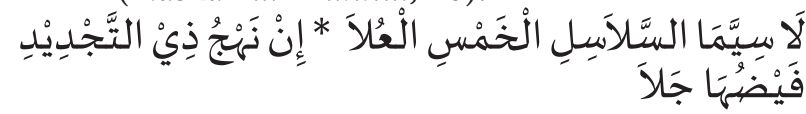

Istimewa lagi segala silsilah yang lima yang tinggi-tinggi itu ${ }^{*}$ karana jalan Syaikh al-
Mujaddidiyah faydnya itu amat nyata (Naskah al-Manhal, 33).

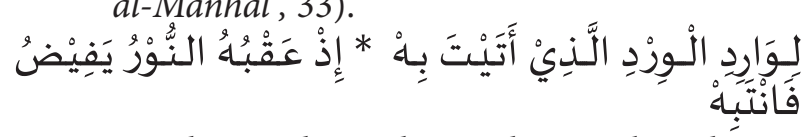

Bagi yang datang daripada wirid yang akan datang dangan dia itu* karana mengiringi akan dia itu $n \bar{u} r$ yang limpah ia maka jaga olehmu (naskah al-Manhal, 35).

Dalam konteks inilah Syaikh Isma'il alMinangkabawi mengajarkan pentingnya al-räbitah yaitu upaya yang dilakukan oleh murid atau sālik dalam menghubungkan rohaninya dengan rohani sang guru murshidnya. Seperti tergambar dalam ungkapan fa-lā budda min wasahin yunāsibu

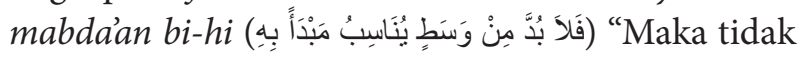
dapat tiada daripada wāsitah yang munāsibah ia akan jadi permulaan dangan dia jua". Dan memang dengan menjadikan rohani guru murshid ini sebagai perantara/al-wasilah atau al-wāsitah (الوسيلة) (أو الوسيطة dipastikan seorang murid atau sālik bisa memperoleh limpahan karunianya, sehingga bisa terhubung dengan Allah swt. Sebagaimana terlihat dalam ungkapannya nastafìdu al-fayd min-hu tataffulā (نَسنَفْيَدُ الْفَيْضَ مِنْهُ تَطَفْفَ) "kita ambil akan fayd daripadanya dangan tatafful jua artinya tatumpang jua".

Al-räbitah pada intinya dilakukan oleh seorang murid dengan cara menghadirkan rupa atau wajah guru murshid ke dalam hati sanubarinya ketika berzikir atau beribadah guna mendapatkan perantara/penghubung (al-wasilah) dalam rangka perjalanan murid menuju Allah swt (Said, H. A. Fuad, 1999: 71). Seorang murid di hadapan guru murshidnya hendaklah menunjukan kelemahan dan ketidakberdayaannya seperti layaknya seorang bayi di tangan seorang ibu. Begitulah kesan yang tergambar dari pemilihan kata tataffulā (تَفَفْ) yang dikemukan oleh Syaikh Isma'il al-Minangkabawi

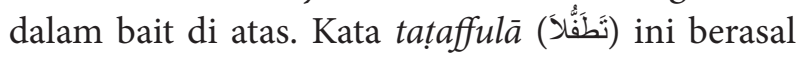
dari kata tifl (طفل) yang secara harfiyah berarti "kanak-kanak atau bayi yang belum bisa berbuat apapun selain hanya mengandalkan pertolongan ibunya atau bantuan pihak lain" (al-Mașrī, ibn Manẓūr al-Afrīqī, tt: 2683). Hal ini menunjukan bahwa dalam al-rābitah, seorang murid hendaklah menyerahkan diri sepenuhnya kepada murshidnya, karena dia belum bisa mengenal, serta tidak mampu mengetahui dan tidak bisa mencapai apapun 
kecuali atas bantuan murshid tersebut. Keadannya itu sama seperti layaknya seorang bayi yang tidak bisa melakukan apa-apa kecuali atas bantuan ibunya atau orang lain di sekitarnya. Rābitah ini dilakukan dengan keyakinan bahwa pada rohani Syaikh murshid itu terdapat roh yang suci atau al-arwāh almuqaddasah (الأرواح المقدة) Rasulullah saw atau nūr Muhammad. Syaikh murshid adalah khalifah Allah swt dan khalifah Rasulullah saw. Sebagai manifestasi daripada nūr Muhammad mereka dianggap dan diyakini sebagai pengantar (al-wasilah) bagi murid menuju Allah swt (Sunyoto, Agus, 2005: 255 dan Aceh, Abu Bakar, 1986: 85-86). Begitulah di antara kesan yang bisa ditangkap seperti disebutkan dalam bait berikut.

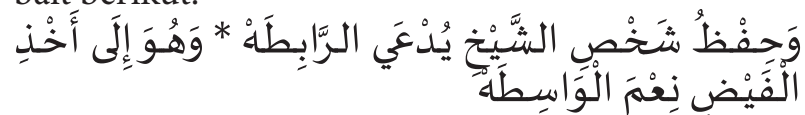

Dan ingat rupa Syaikh itu dinamai akan rābitah * dan yaitu bagi mengambil fayd itu sebaikbaik wāsitah

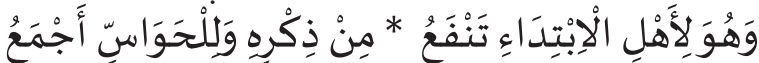

Dan yaitu bagi yang mubtadi terlebih manfaat * daripada zikirnya itu dan bagi pengenalan terlebih mehimpunkan

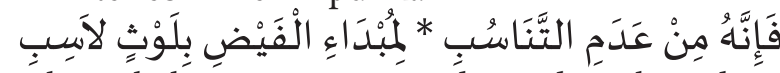

Maka bahwasanya ia daripada ketiadaan munāsabah* bagi permulaan fayd itu dangan cemar-cemar yang terlekat

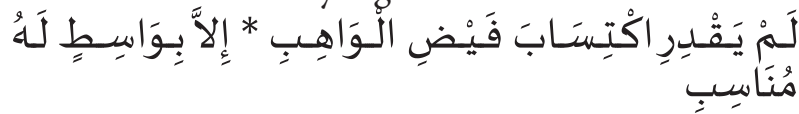

Tiada kuasa ia akan menghasilkan fayd Tuhan Yang Mengarunai* melainkan dangan wäsițah baginya yang munāsib (naskah al-Manhal, 39).

Dalam konteks ini, maka al-rābițah memang menuntut seorang murid atau sālik untuk selalu menghubungkan rohaninya dengan rohani guru murshidnya. Sebagaimana dalam ungkapan Syaikh Isma'il al-Minangkabawi pada kalimat wa-hifz

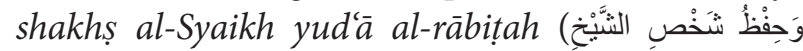
"Dan ingat rupa Syaikh itu dinamai akan rābițah". Kata hifz (حفْظُ) memang secara harfiyah berarti tetap dalam pemeliharaan dan tidak boleh lepas walaupun sesaat. Karena, seorang guru murshid dengan kelebihan, kemulian dan kewalian yang dimilikinya akan memberikan limpahannya kepada sang murid atau sālik untuk kemudian mengantarkan sang murid ke alam rohani yang lebih tinggi. Dan al-rābitah ini dianggap sebaikbaik perantara menuju Tuhan, sebagaimana dalam ungkapannya wa-huwa ilá akhdh al-fayd ni'ma al-

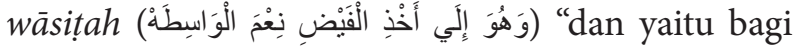
mengambil fayḍ itu sebaik-baik wāsițah".

Dalam konteks ini ternyata juga Syaikh Ismail al-Minangkabawi memberikan persyaratan ketat bahwa seorang murshid yang bisa menjadi wasilah tersebut hanyalah murshid yang kāmil mukammil. Mereka adalah murshid yang telah mencapai keparipurnaan márifatullāh sebagai insān yang $k a \bar{m} i l$, sekaligus bisa memberikan bimbingan jalan keparipurnaan bagi para pengikut atau muridmuridnya. Tipikal murshid seperti inilah yang disebut dengan "Syaikh" atau "guru murshid" yang maqām spritualnya sudah berada dalam taraf kewalian. Dan kewalian yang dalam wujud guru murshid yang kāmil lagi mukammil seperti inilah yang dianggap layak dan mampu memberikan bimbingan kepada muridnya menuju Tuhan. Konsepsi kewalian seperti juga telah digambarkan di dalam al-Qur'an yang disebut juga dengan istilah waliyyan murshidan (وليا مرشدا) "wali yang mampu memberikan bimbingan".

Perpaduan antara kewalian dan kemurshidan inilah yang menjadi prasyarat bagi munculnya seorang murshid yang kāmil dan mukammil. Mereka adalah wali, karena sudah mencapai alam ma'rifat dengan sempurna, sekaligus juga murshid karena memiliki kemampuan untuk menunjukan dan mengantarkan orang lain untuk juga bisa mencapai kedudukan yang telah dicapainya tersebut. Dalam bait-baitnya Syaikh Isma'il al-Minangkabawi juga menegaskan hal itu.

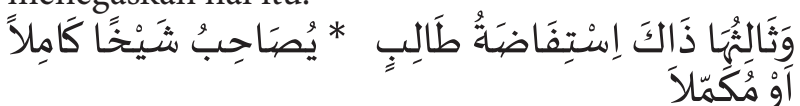

Dan yang ketiga daripada jalan itu ialah menuntut tâlib itu akan fay t $^{*}$ yang menyertai ia akan Syaikh yang kāmil pada dirinya lagi mengkāmilkan bagi lainnya

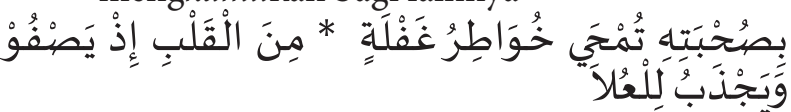

Dangan sebab menyertai dia itu dihapus akan segala khātir dan akan ghaflah itu* daripada hati tatakala hening ia dan dihilakan akan dia bagi Yang Maha Tinggi (Naskah al-Manhal,18).

Dalam bait ini ditegaskan, bahwa seorang 
murid atau sālik memang harus berusaha mendapat limpahan (al-fayd) dari rohani guru murshid tersebut untuk mencapai tingkat spiritual lebih tinggi, yaitu bisa berhubungan dengan Allah swt. Hal itu dipahami dari ungkapan wa-thālithuhā dhāka istifādat tạlibin

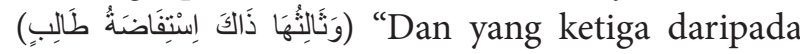
jalan itu ialah menuntut tâlib itu akan fay ḍ". Namun, untuk mendapatkan limpahan sang guru murshid tersebut, seorang murid harus melakukun proses al-rābitah dan al-tawassul. Sedangkan, proses ini tidaklah boleh kepada semua guru, tetapi hanyalah kepada Syaikh yang dipercaya dan diyakini sudah mencapai tingkat wali yang rohaninya sudah kamil lagi mukammil. Sebagaimana dalam ungkapannya yuṣāhibu shaykhan kāmilan aw-mukammilan (يُصَاحِبُ

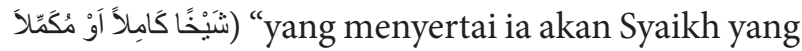
kamil pada dirinya lagi mengkamilkan bagi lainnya”.

Bahkan, dalam konteks ajaran al-räbitah dan al-tawassul ini dikenal pula istilah al-tawajjuh yaitu seorang sālik berupaya membuka hatinya dan membayangkan hatinya disirami berkah sang Syaikh murshidnya. Melalui al-tawajjuh ini, sang Syaikh akhirnya membawa hati murid tersebut ke hadapan rohani nabi Muhammad saw. Selanjutnya, atas bantuan rohani nabi Muhammad saw, rohani murid tersebut dibawa ke hadapan Allah swt dalam posisi inilah seorang sālik kemudian berhak atau telah bisa merasakan limpahan karunia-Nya (al-fuyzūd). Dalam proses pemusatan konsentrasi timbal balik antara murid dan Syaikh ini, akan menghasilkan penyatuan rohani dan akan melahirkan sejumlah gejala kebatinan lainnya, yang wujud dan bentuknya tidak bisa diceritakan ataupun digambarkan secara verbal oleh sang murid atau sālik tersebut (Kabbani, Muhammad Hisham, 2004: 644-645 dan Buehler, Arthur F, 1998: 133).

Adapun al-tawajjuh hanya boleh kepada guru yang sudah disebut murshid, seperti bait berikut.

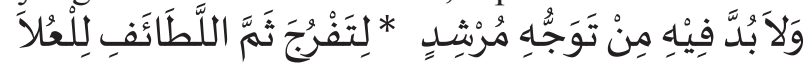
Dan tidak dapat tiada daripadanya itu daripada tawajjuh murshid ${ }^{*}$ supaya naik daripada di sana itu segala latẩif itu bagi Yang Maha Tinggi
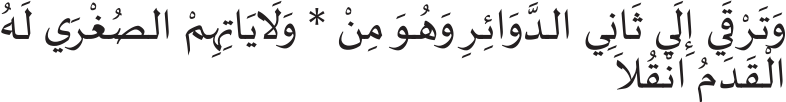

Dan naik-naik engkau daripada yang kedua daripada segala dairah dan yaitu daripada * wilāyah mereka itu yang kecil baginya itu pindahkan olehmu akan tapak kaki

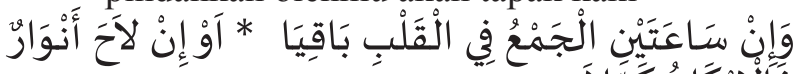

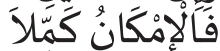

Dan jika dua saat jam iyah itu di dalam hati padahalnya berkekalan* atau jika nyata beberapa nūr maka dā'irah al-imkān itu telah sempurna ia (Naskah al-Manhal, 22).

Dalam baitini, Syaikh Isma ilal-Minangkabawi menegaskan, bahwa hanya Syaikh yang disebut murshid saja yang berhak dijadikan sebagai tempat al-tawajjuh bagi muridnya. Hal itu terlihat dari ungkapan Syaikh Isma'il al-Minangkabawi pada kalimat wa-lā-budda fìhi min tawajjuh murshidin (وَ)

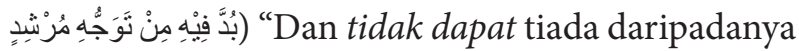
itu daripada tawajjuh murshid". Secara kebahasaan menarik mencermati pola ungkapan bait ini, di

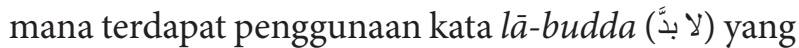
berarti "tidak dapat tiada" atau bisa juga diartikan mestilah yang mengandung arti wajib. Begitu pula, pola ungkapan degan mendahulukan prediket (al-khabar), yaitu fî̀-hi (فيه) "padanya" daripada subjeknya (al-mubtadä), yaitu min tawajjuhi murshidin (من توجه مرشد) "daripada tawajjuh murshid" yang mengandung arti terfokus atau terbatas. Pola ini yang dikenal dalam ilmu baläghah dengan istilah taqdìm mā haqquhu al-ta'khīr (تقديم ما حقه التخير), dan merupakan salah satu pola al-qaṣr (القصر (tidak ada atau tidak boleh yang lain kecuali hanya itu saja" (alHāshimī, Aḥmad, tt: 17 ). Dengan ungkapan pola kalimat seperti ini, merupakan penegasan Syaikh Isma il al-Minangkabawi bahwa hanya guru murshid saja yang berhak dijadikan tempat al-tawajjuh bagi muridnya tidak boleh yang lainnya.

Bait-bait di atas menegaskan, bahwa hanya syaikh yang kapasitasnya murshid yang dipercaya dan diyakini sebagai figur otoritatif dan karenanya dianggap paling berhak menuntun murid-muridnya dalam mengarungi perjalanan spiritual. Hal itu disebabkan bahwa seorang murshid merupakan sosok yang diyakini sebagai orang yang telah sampai pada taraf al-mahfüz (terpelihara dari dosa) (Mufid, Ahmad Syafi'I, 2006: 249). Selain itu, guru murshid juga merupakan sosok yang sudah dipercaya kewenangannya dalam mengajarkan ajaran tarekat kepada murid-muridnya, karena otoritas yang dimilikinya berupa ijazah dari murshid sebelumnya yang berlaku dan diterima secara langsung dan menurut jalur yang mutawatir dengan sanad yang 
bersambung (Huda, Sokhi, 2008: 63). Dalam konteks inilah, guru murshid sekaligus juga diyakini sebagai orang yang berhak dan berwenang pula memberikan ijazah tarekat, jika seorang murid dianggap telah layak mendapatkannya atas mencapaian spritualnya dengan kesungguhan latihan (al-riyādah) yang telah dilaluinya.

\section{Reformulasi Konsep Transendensi dan Imanensi Tuhan}

Seperti dijelaskan, bahwa jauh sebelum Syaikh Isma'il al-Minangkabawi muncul sebagai tokoh tarekat Naqshabandiyah, di Nusantara sendiri telah berkembang beberapa corak ajaran sufistik. Di antaranya seperti diungkap banyak ahli, terdapat tasawuf dengan corak akhlāqì dan ada tasawuf dengan corak falsafi. Sebagai seorang sufi yang muncul pada periode belakangan, tampaknya Syaikh Isma'il al-Minangkabawi tidak bisa dilepaskan dari kecenderungan terhadap salah satu dari beberapa corak ataupun aliran sufistik yang telah berkembang sebelumnya di Nusantara. Dalam konteks ini terlihat adanya kecenderungan aliran falsafi dalam ajaran sufistiknya. Di antaranya tentang immanensi Tuhan dengan makhluk, yaitu ketika terjadi peleburan makhluk dengan Tuhan saat keadaan al-fana $\vec{a}$ (الفناء). Hal itu sebagaimana terlihat dalam ungkapan berikut.

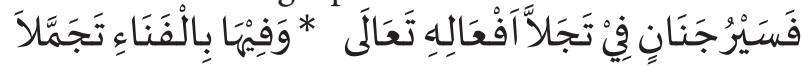

Maka perjalanan hati itu pada tajalli segala $a f^{\prime} \bar{a} l$ Tuhan Yang Maha Tinggi* dan padanya itu dangan fanā telah nyata bersifat Ia

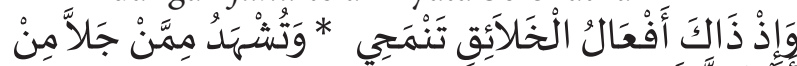
أَنَّ يُمَثَّلَاَ

Dan tatkala itu sekalian perbuatan khalā'iq itu hapuslah ia* dan dipandang perbuatan itu hanyalah daripada Tuhan Yang Maha Suci daripada dimisalkan jua

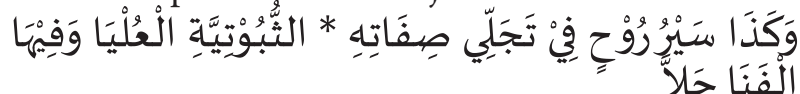

Demikian lagi perjalanan ruh pada tajjalī segala sifat Tuhan* yang thubütiyah Yang Maha Tinggi dan padanya itulah fanā itu nyata ia

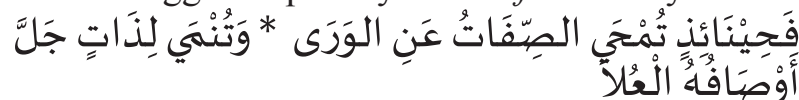

Maka pada kutika ini dihapuslah segala sifat daripada segala makhluk * dan bangsalah akan dia bagi Zat Yang Maha Besar segala sifat-Nya yang tinggi

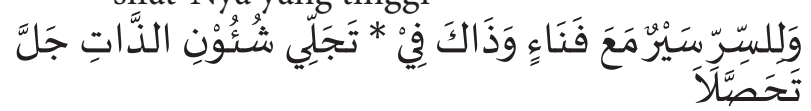

Dan bagi sirr itu perjalanan serta fan $\bar{a}^{\prime}$ dan yang demikian itu pada* tajallī syu'ūn al-Dhāt Yang Maha Besar itu hasil ia

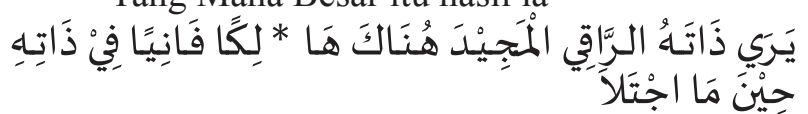

Melihat ia akan zat yang naik ia lagi mulia ia di sana itu * akan lenyap lagi fanā' di dalam ZatNya Yang Maha Tinggi pada waktu yang tajallī Ia (Naskah al-Manhal, (25).

Dalam bait-bait ini, dijelaskan bagaimana ketika seorang sālik yang telah fanā' dan akan memperoleh tajallī bersama Tuhan. Pada saat fan $\bar{a}$, ini terjadi, hilanglah segala sifat kemakhlukannya dan kemudian menyatu dengan sifat nāsutnya Tuhan. Ketika makhluk telah mencapai fanā' ini, maka otomatis dia akan lebur bersama Tuhan dalam segala kebesaran-Nya. Hal itu seperti terlihat dalam ungkapan Syaikh Isma'il al-Minangkabawi pada kalimat fa-hīna'idhin tumhāa al-șifât 'an al-warā,

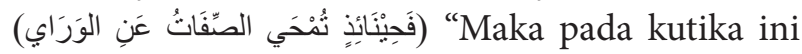
dihapuslah segala sifat daripada segala makhluk". Kemudian, dilanjutkan dengan ungkapannya $w a-$

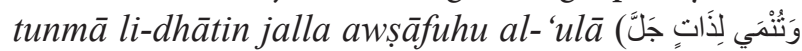

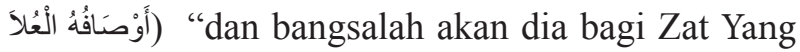
Maha Besar segala sifat-Nya yang tinggi".

Paham penyatuan makhluk dengan Tuhan ini sangat mirip dengan apa yang pernah dikemukakan oleh Abū Yazīd al-Buștāmi tentang konsep al-ittiḥād. Namun demikian, terdapat perbedaan yang cukup prinsipil dengan apa yang diajarkan oleh Abū Yazīd al-Bușțāmi dalam paham al-ittiḥādnya tersebut. Di mana dalam ajaran tarekat Naqshabandiyah yang diajarkan Syaikh Isma'il al-Minangkabawi, kondisi al-fană yang membawa seorang sālik berada pada puncak kenikmatan rohani sehingga dia lebur dan mengalami penyatuan diri dengan Tuhan tidak sampai melahirkan ungkapan-ungkapan aneh layaknya seorang yang mabuk atau yang biasa disebut dengan istilah al-shatāhat.

Dalam bait yang lain, Syaikh Isma'il alMinangkabawi menggambarkan penyatuan makhluk dengan Tuhan tersebut, yaitu setelah keduanya lebur menjadi satu dengan menyebutnya sebagai dua wujud dalam satu kesatuan. Syaikh 
Isma'il al-Minangkabawi menyebut keduanya sebagai wujūd haqqiqui dan wujūd majāzi dan antara keduanya walaupun bersatu, namun tetap berbeda. Hal itu seperti terlihat dalam bait berikut.

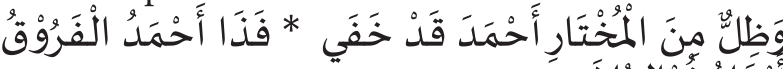

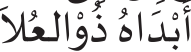

Dan bayang-bayang daripada Nabi yang mukhtār Aḥmad sungguhnya telah tersembunyi maka inilah imām Aḥmad al-Farūq menyatakan akan dia oleh Tuhan (Naskah al-Manhal, 27)

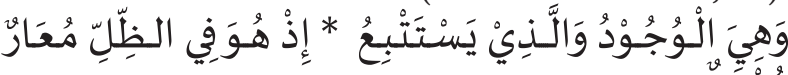

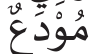

Dan amanah itu ialah wujūd dan yang mengikut dia * karana wujūd pada bayang-bayang itu dipinjam dan dan dipitaruhkan jua

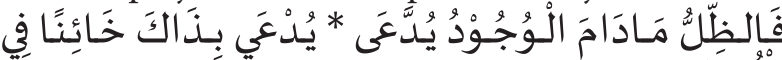

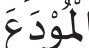

Maka bayang-bayang itu selama berkekalan dinamakan ada $^{\star}$ niscaya dinamai ia dangan yang demikian itu khianat pada yang dipitaruhkan itu

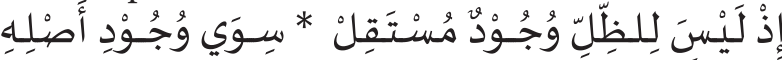

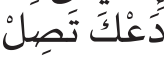

Karana tiada ia bagi bayang-bayang itu wujūd yang mustaqil* lain daripada wujūd asalnya itu tinggal olehmu akan dirimu niscaya sampailah engkau

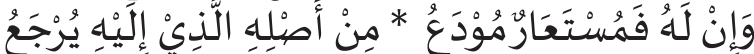

Dan jika ada bagimu wujūd maka dipinjam jua lagi diambil $^{*}$ daripada asalnya yang kepada-Nya kembali ia (Naskah al-Manhal, 37).

Syaikh Isma'il al-Minangkabawi menyebutkan bahwa wujūd alam semesta ini hanyalah wujūd majāzì dan merupakan bayangan seperti terlihat jelas pada ungkapan idh huwa fì al-żilli mu'ārun

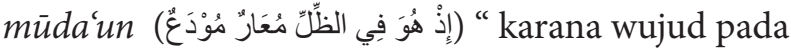
bayang-bayang itu dipinjam dan dipitaruhkan jua”. Sementara wujūd haqī $\bar{\imath}$ adalah wujud Tuhan yang merupakan Wujūd yang sebenarnya, sebagaimana terlihat dalam ungkapan idh laysa li-al-zilli wujūdun

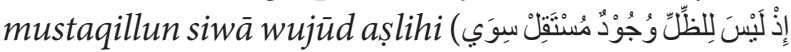
" Karana tiada ia bagi bayang-bayang itu wujūd yang mustaqil lain daripada wujūd asalnya”. Namun demikian, alam yang disebut sebagai wujūd majāzì adalah gambaran dari wujū dan merupakan cermin sejati dari wujūd haqīqi itu serta bersifat mengikuti-Nya dalam segala sifat-Nya. Hal itu sebagaimana tergambar dari ungkapannya

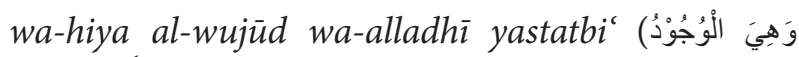

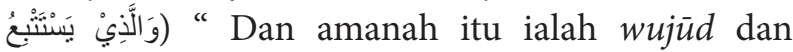
yang mengikut dia”. Di sini terlihat, bahwa Syaikh Ismail al-Minangkabawi tetap mempertahankan transendesi Tuhan dengan makhluk sekalipun pada prinsipnya bahwa Tuhan dengan makhluk juga bersifat immanen. Ajaran ini sangat mirip dengan konsep sufistik yang diajarkan oleh alSinkili tentang wahdat al-wujūdnya yang sekalipun mengakui imanensi Tuhan dengan alam, namun dia tetap mempertahankan transendesi Tuhan (Azra, Azyumardi, 1994: 206 dan Salam, Aprinus, 2004: 35).

Begitulah corak pemahaman tasawuf Syaikh Isma'il al-Minangkabawi yang lebih cenderung falsafì dan sepintas sangat dekat dengan ajaran tasawuf Abū Yazìd al-Busțāmī dan Ibn 'Arabī (Kartal, Abdullah, 2013: 171-180). Kedekatan itu terlihat terutama dalam hal pemahaman tentang hubungan Tuhan dan alam, walaupun konsepnya tidak persis bisa disamakan. Memang konsep al-ittihāa dan wahdat al-wujūd telah mempengaruhi ajaran sufistik Syaikh Isma'il al-Minangkabawi, namun dalam pemahamannya tetap terdapat perbedaan. Pada kenyataannya memang tidak bisa dipungkiri bahwa dalam silsilah ajarannya Syaikh Isma'il alMinangkabawi menyebutkan nama Abū Yazīd alBusțāmī sebagai salah satu rangkaian silsilah Syaikh tarekat Naqshabandiyah yang dikembangkannya seperti dalam bait berikut.

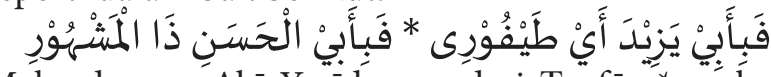

Maka dengan Abì Yazid yang dari Ṭayfūr * maka dengan Abù al-Hasan yang memiliki kemasyhuran (naskah Nazm, 1).

Tentu saja kenyataan ini tidak berarti bahwa ajaran Syaikh Isma'il al-Minangkabawi mengambil secara utuh konsep-konsep sufistik yang pernah diajarkan Abū Yazìd al-Busțāmī. Dalam konteks ini memang terdapat hubungan ajaran tarekat Naqshabandiyah dengan ajaran Abū Yazīd alBusțāmī yang bukan hanya dalam persoalan ritual dan tata cara amalan saja, namun juga terkait dengan doktrin ajaran sufistiknya. Akan tetapi, sekali lagi penulis tegaskan bahwa dalam konteks tertentu Syaikh Isma'il al-Minangkabawi tidak sepenuhnya mengambil doktrin ajaran Abū Yazīd al- Busțāmī, terutama dalam ajaran al-shațāhāt yang tidak dimiliki Syaikh Isma'il al-Minangkabawi 
dalam ajarannya.

Hal ini juga yang membedakan Syaikh Isma'il al-Minangkabawi dengan tokoh utama tarekat Naqshabandiyah seperti Syaikh Ahmad Sirhindī yang sangat tegas menentang paham wahdat alshuhūd dan wahdat al-wujūd yang dikembang oleh Syaikh Abū Yazīd al-Busțāmī dan Ibn 'Arabī (Kartal, 2013: 171-180). Kenyataan ini tentu saja berbedah jauh dengan pendapat dan pandangan beberapa ahli yang selama ini mengatakan bahwa Syaikh Isma'il al-Minangkabawi dianggap sebagai salah satu tokoh sufi Nusantara abad 19 M yang berjasa besar dalam melakukan pemurnian terhadap ajaran tasawuf dengan membuang ajaran wahdat al-wujūd dalam konsep ajarannya (Mufid, 2006: 65). Ternyata dalam konsep ajaran tarekat yang dikembangkannya, Syaikh Isma'il al-Minangkababwi berupaya melakukan sintesa (upaya kompromi) dua corak ajaran tasawuf besar yaitu ajaran tasawuf akhlaki dan falsafi ke dalam "tubuh ajaran tasawuf baru" yang bernama tarekat Naqshabandiyah Khalidiyah.

Memang, sampai sejauh ini penulis belum menemukan alasan atau latar belakang Syaikh Isma’il al-Minangkabawi melakukan upaya sintesa tarekat Naqshabandiyah Khalidiyah yang selama ini lebih berorientasi akhlāqī dengan memasukan konsep-konsep ajaran falsafì ke dalam ajaran yang dikembangkannya di Nusantara. Penulis menduga bahwa upaya sintesa kedua ajaran tasawuf yang berbeda ini dilakukan Syaikh Isma'il alMinangkabawi ketika berada di Nusantara, lebih dilatarbelakangi dua faktor; eksternal dan internal.

Secara eksternal, pengikut awal ajaran tarekat ini yang merupakan lingkungan istana dengan tingkat dan cara berfikir yang tentu saja sudah lebih maju. Di samping itu, masyarakat yang menjadi pengikut awal ajaran tarekat Naqshabandiyah Khalidiyah ini di Nusantara adalah masyarakat yang mendiami kawasan pesisir dalam hal ini Singapura dan Kerajaan Riau Lingga di Pulau Penyengat. Masyarakat pesisir adalah masyarakat yang bersifat heterogen, dinamis dan memiliki cara berfikir yang cenderung filosofis. Memasukan unsur-unsur filosofis atau konsep-konsep tasawuffalsafì ke dalam ajaran tarekat yang dikembangkan tentu akan lebih menarik bagi para pengikutnya dengan karakter seperti disebutkan.

Sementara faktor internal dilatarbelakangi faktor keilmuan Syaikh Ismail al-Minangkabawi yang memiliki kekayaan intelektual dan spritualnya karena telah belajar kepada banyak guru di Haramain dan juga di luar Haramain. Dia tidak hanya belajar satu keilmuan tertentu, namun mempelajari beragam ilmu keislaman. Tentu saja, tidak berlebihan jika diduga kuat Syaikh Isma'il al-Minangkabawi tidak hanya mempelajari satu ajaran tarekat saja, namun juga ajaran tarekat lain. Hal itu terbukti dengan lahirnya salah satu karyanya berjudul Māwahib Rabb al-Falaq yang merupakan syarahan dari bait-bait qașīdah Nāsīr al-Dīn binti al-Milaq salah satu tokoh ajaran tarekat Shādhiliyah. Sehingga, tidak tertutup kemungkinan Syaikh Ismail al-Minangkabawi juga mempelajari tarekat Syattariyah yang dikenal sebagai tasawuf dengan corak falsafì.

\section{PENUTUP}

Dari penjelasan di atas terlihat upaya Syaikh Isma'il al-Minangkabawi dalam mendamaikan dua jaran tasawuf besar yang berkembang di dunia Islam; akhlaki dan falsafi dengan melakukan sintesa antara kedua. Tentu saja sebuah upaya yang belum pernah dilakukan para syaikh dan tokoh tarekat Naqshabandiyah sebelumnya. Seperti di ketahui, semenjak berdirinya ajaran tarekat Naqshabandiyah yang digagas Syaikh Bahä' al-Dīn al-Naqshabandī (w. 1389 M), hingga masa Khalīd al-Kurdī (w.1827 M) di Jabal Qubays, ajaran tarekat Naqshabandiyah ini lebih berorientasi kepada zikir dan ritual murni sebagai upaya mendekatkan diri kepada Allah swt sehingga terbentuk akhlak mulia bagi para pengikutnya. Hal itu bisa dilihat dari karya-karya tokoh tarekat Naqshabandiyah yang pernah di tulis di Timur Tengah seperti Jāmi' al-Ușūl fì al-Awliyā' karya Al-Gumuskhanawī (w. 1893 M), Tanwìr alQulūb karya Kurdī (w. 1914 M) dan lainnya.

Ketika ajaran tarekat ini dikembangkan di Nusantara, Syaikh Isma'il al-Minangkabawi mencoba melakukan formulasi baru dengan mencoba melakukan sintesa dengan ajaran tasawuf yang bersifat falsafī dalam konteks memberikan penjelasan lebih filosofi terhadap konsep-konsep dasar ajaran tarekat Naqshabandiyah yang dikembangkannya. Memang Syaikh Ismacil alMinangkabawi tidak mengubah ajaran tarekat Naqshabandiyah yang diajarkannnya atau 
melakukakan penyimpangan dari konsep-konsep ajaran dasar yang telah dirumuskan Syaikh Naqshabandiyah terdahulu, namun dia berupaya menjelaskan konsep-konsep tersebut secara lebih dalam dan filosofis.

\section{UCAPAN TERIMA KASIH}

Tulisan ini tidak terlepas dari masukan berbagai pihak, terkhusus penulis aturkan terima kasih kepada Dosen Pembimbing penulis, rekan mahasiswa PPs UIN Syarif Hidayatullah Jakarta atas kritik, saran dan masukannya terhadap tulisan ini. Kepada tim redaksi Jurnal Al Qalam terima kasih banyak atas termuatnya tulisan ini.

\section{DAFTAR PUSTAKA}

'Abd al-Jabbār, Umar. 1982. Siyar wa-Tarājim: Ba'd 'Ulamäinā fi al-Qarn al-Rābi' 'Ashar li-alHijrah. Jeddah: Al-Mamlakah al-Arabīyah al-Sa ūdīyah.

Abdullah, Wan Mohd. Shaghir. 1993. Penjelasan Nazham Syair Shufi Syeikh Ahmad al-Fathani. Kulala Lumpur: Khazanah Fathiyah.

Aceh, Abu Bakar. 1986. Pengantar Ilmu Tarekat: Uraian Tentang Mystik. Solo: Ramadhani.

Atjeh, Aboebakar. 1985. Pengantar ilmu Tarekat. Solo: CV. Ramadhani.

Azra, Azyumardi. 2005. Dari Harvard Hingga Makkah. Jakarta: Penerbit Republika.

Azra, Azyumardi. 2003. Surau: Pendidikan Islam Tradisional dalam Transisi dan Modernisasi. Ciputat: PT Logos Wacana Ilmu.

Azra, Azyumardi. 1994. Jaringan Ulama Timur Tengah dan Kepulauan Nusantara Abad XVII dan XVIII: Melacak Akar-Akar Pembaruan Pemikiran Islam di Indonesia. Bandung: Mizan.

Al-Bakrī, Abū al-Fayḍ 'Abd al-Sattār ibn 'Abd alWahhāb. 2009. Fayḍ al-Mālik al-Wahhāb alMutaālì bi-Abnāi Awāil al-Qarn al-Thālith Ashar wa-al-Tawāli Jilid 1. Makkah alMukarramah: Maktabat al-Asadìyah.

Bruinessen, Martin van. "After The Days of Abu Qubays: Indonesian Tranformations of The Naqsyabandyya-Khalidiya". Journal of The History of Sufism 5 (2007)

Bruinessen, Martin van. 1992. Tarekat
Naqsyabandiyah di Indonesia: Suvei Historis, Geografis, dan Sosiologis. Bandung: Mizan.

Buehler, Arthur F. 1998. Sufi Heirs of The Prophet; The Indian Naqshbandiyya and The Rise of The Mediating Sufi Syaikh. Colimbia: University of South Carolina Press.

Effendy, Mochtar. 2001. Ensiklopedi Agama dan Filsafat, Volume 3. Palembang: Universitas Sriwijaya.

Fathurahman, Oman. 1999. Tanbīh al-Māsyī: Menyoal Wahdatul Wujud Kasus Abdurrauf Singkel di Aceh Abad 17. Bandung: Mizan.

Feener, R. Michael., Sevea, Terenjit. 2009. Islamic Connection: Studies of South and Southeast Asia. Singapore: Institute of Southeast Asian Studies.

Hamdi, Aḥmad Zainul. 2004. Tujuh Filsuf Muslim: Pembuka Pintu Gerbang Filsafat Barat dan Modern. Yogyakarta: Pustaka Pesantren.

Al-Hāshimī, Aḥmad. tt. Jawāhir al-Balāghah fi alMå̄ñ̄ wa al-Bayān wa al-Badī‘. Beirut: alMaktabah al-Așrìyah,

Huda, Shoki. 2008. Tasawuf Kultural: Fenomena Shalawat Wahidiyah. Yogyakarat: LKiS.

Ibn 'Arabī, Muhyy al-Dīn. 1985. Al-Futūhāt alMakìyah, Juz I, Tahqīq 'Uthmān Yahyá. Mișr: Al-Hay’ah al-Mișrīyah al-Āmmah li-al-Kitāb.

Johns, A.H. "Reflections on the Mysticism of Shams al-Dīn al-Sumațāāi (1550-1630), Studia Islamika Indonesian Journal for Islamic Studies, Vol. 18, Number 2, (2011).

Kabbani, Muhammad Hisham. 2004. Classical Islam and The Naqshbandi Sufi Tradition. Oakland: Islamic Supreme Council of America (ISCA).

Kartal, Abdullah. "Ahmad Sirhindi's Criticim of Wahdat al-Wujūd and its Historical Background". International Journal of Business and Social Science, Vol. 4, No. 1 (Januari 2013).

Masruri, M. Hadi. 2005. Ibn Thufail:Jalan Pencerahan Mencari Tuhan. Yogyakarta: LKiS.

Al-Mașrī, Abū al-Faḍal Jamāl al-Dīn Muḥammad ibn Mukarram ibn Manz̄ūr al-Afrīqī. tt. Lisān al-Áab. Al-Qāhirah: Dār al-Maārif.

Mufid, Ahmad Syafi'i. 2006. Tangklukan, Abangan, dan Tarekat: Kebangkitan Agama di Jawa. Jakarta: Yayasan Obor Indonesia.

Mujieb, M. Abdul., et.al. 2009. Ensiklopedi Tasawuf Imam al-Ghazali: Mudah Memahami dan 
Menjalani Kehidupan Spritual. Jakarta: PT. Mizan Publika.

Nasution, Harun. 1973. Filsafat dan Mistisisme dalam Islam. Jakarta: Bulan Bintang.

Noer, Kautsar Azhari. 1995. Ibn al-Arabi: Wahdat al-Wujud dalam Perdebatan. Jakarta: Paramadina.

Al-Rumānī, Abū al-Ḥasan 'Alī ibn 'Īsā. tt. Ma'ānī alHurūf. Beirut: Al-Maktabah al-Așriyah.

Said, H. A. Fuad. 1999. Hakikat Tarikat Naqsyabandiyah. Jakarta: Al-Husna Zikra.

Salam, Aprinus. 2004. Oposisi Sastra Sufi. Yogyakarta: LKiS.

Shihab, Alwi. 2001. Islam Sufistik: "Islam Pertama" dan Pengaruhnya Hingga Kini di Indonesia. Mizan: Bandung.

Solohin, M., Anwar, Rosihan. 2002. Kamus Tasawuf. Bandung: PT. Remaja Rosdakraya.

Sholikhin, Muhammad. 2010. Menyatu Diri Dengan Ilahi: Makrifat Ruhani Syaikh 'Abd al-Qadir al-Jailani dan Perspektifnya Terhadap Paham Manunggaling Kawula Gusti. Yogyakarta: Narasi.
Sholikhin, Muhammad. 2009. 17 Jalan Menggapai Mahkota Sufi Syaikh Abdul Qadir al-Jailani. Yogyakarta: Mutiara Media.

Sholikhin, Muhammad. 2008. Filsafat dan Metafisika dalam Islam: Sebuah Penjelajahan Nalar, Pengalaman Mistik dan Perjalanan Aliran Manunggaling Kawula-Gusti. Yogyakarta: Narasi.

Sholihin, M. 2005. Melacak Pemikiran Tasawuf di Nusantara. Jakarta: PT. Raja Grafindo Persada.

Solihin, M. 2005. Melacak Pemikiran Tasawuf di Nusantara. Jakarta: Raja Grafindo Persada.

Sj, A. Sudiarja. dkk (Penyunting). 2006. Karya Lengkap Drikarya: Esai-Esai Filsafat Pemikir yang Terlibat Penuh dalam Perjuangan Bangsanya. Jakarta: PT. Gramedia Pustaka Utama kerjasama antara PT. Kompas Media Nusantara.

Sunyoto, Agus. 2005. Sulūk Abdul Jalil, Perjalanan Sufi Syaikh Siti Jenar Volume 2. Yogyakarta: Pustaka Sastra LKiS. 